\title{
The Peculiarities of Perspective Students Selection Mechanism by the Future Employers-Enterprise
}

\author{
Albina R. Shaidullina ${ }^{1}$, Elena E. Merzon ${ }^{2}$, Venera G. Zakirova ${ }^{3}$, Ekaterina V. Mokeyeva ${ }^{3}$, Boris A. Karev ${ }^{4}$, Elena \\ A. Burdukovskaya ${ }^{4} \&$ Natalya M. Polevaya ${ }^{4}$ \\ ${ }^{1}$ Almetyevsk State Oil Institute, Almetyevsk, Russia \\ ${ }^{2}$ Yelabuga Institute of Kazan Federal University, Yelabuga, Russia \\ ${ }^{3}$ Kazan Federal University, Kazan, Russia \\ ${ }^{4}$ Amur State University, Blagoveschensk, Russia \\ Correspondence: Albina R. Shaidullina, Foreign Languages' Department, Almetyevsk State Oil Institute, \\ Almetyevsk, 423450, Russia. E-mail: albina-plus@mail.ru
}

Received: October 24, 2014 Accepted: December 3, $2014 \quad$ Online Published: December 18, 2014

doi:10.5539/res.v7n1p68

URL: http://dx.doi.org/10.5539/res.v7n1p68

\begin{abstract}
The search of qualified staff is an up-to-date problem for all enterprises. In this regard the aim of the research is the development of perspective students selection mechanism by the future employers. One of the sub-stages of the algorithm is the formation of the resource and reserve groups of students by the enterprise representatives and by tutors of the faculty of professional educational institutions. The formation of the resource and reserve groups of students with flexible system of transition from one group into another according to the results of their progress, according to participation extracurricular life of the institute, participation at the international, All-Russian scientific and practical conferences, allow to intensify the process of their self-preparation by means of creation of the natural competitive environment in educational institution of professional education. It also helps to do the selection by employers and to distribute perspective students taking into account their potential opportunities and professional interests.
\end{abstract}

Keywords: perspective students, resource group, reserve group, competitive environment, selection, mechanism, enterprise, employers

\section{Introduction}

There are Chambers of Commerce and Industry in the majority of regions of Russia. They are carrying out a complex of various services, they solve problems of searching the staff. There the departments, the recruitment agencies realizing projects on development of a labor market, directed on the solution of problems of shortage of qualified staff are created. Also the informational bases of vacancies are created and supported. (Mukhametzyanova \& Shaidullina, 2011). Mainly the staff recruitment agencies apply a wide range of search workers methods: via mass media, via Internet, in their own database, with the help of the technology of direct search of experts with various techniques of candidates selection: using all means from evaluating tests till procedures of the substantial analysis (Ivanov et al., 2010).

The top managers of the enterprises prefer to use external sources of the staff search where the big share is occupied by mass media. It proves once again that the heads of the enterprises do not trust specialists too much in the matter that actually is justified if one take into account that the direction of the centers for search of the staff is generally reduced to such methods as at the Headhunting and Assessment center which essence is the passing of the participants through a series of the various tests: business and role-playing games, professional and psychological tests, self-presentations, discussions, exercises, written works (Smirnov \& Tkachenko, 2004). The usual duration of estimated session is one-two days. Then all the received information is studied attentively and each participant receives the conclusion with an assessment of his or her business and personal qualities, the forecast of professional activity and recommendations about professional and personal development.

We agree that the expert has to be engaged in the selection and hiring of the staff. However these experts can lose work under modern demographic conditions and without close connection of educational institutions and production because there will be nobody to choose soon. Therefore, this error method of perspective staff search 
should be replaced by more perfect one to minimize mistakes looking for valuable employees.

\section{Materials and Methods}

JSC Tatneft used testing system on each subject for selection of students. In our opinion, it didn't solve a problem of determination of their professional suitability as these means of single diagnostics didn't allow distinguishing of the student gifted by nature from "brought" because a number of professional and significant personal characteristics of the student are dropped out of consideration. Therefore the criteria of system selection of students to resource group were developed by us in addition to those testing offered by JSC Tatneft.

The motivational criterion is characterized by the attitude to activity, by awareness of the personal and professional importance of acquired knowledge of future professional activity, by existence of positive motive to training, personal sense in future professional activity, by existence of constant informative interest to the solution of professional tasks, by satisfaction with the career choice. This criterion includes the following indicators: understanding of essence of future professional activity; awareness of the importance of gained knowledge, abilities and competences for effective professional activity; awareness of continuous education necessity, self-education, self-development for successful professional activity.

The cognitive criterion is characterized by professional knowledge about object and the subject of work, by awareness of the professional interests and abilities, by the compliance to requirements of an acquired profession, and also by the prospects of professional career growth. This criterion includes the following indicators: efficiency of use of knowledge in practical activities; the volume of knowledge in comparison with the educational standard; application of knowledge in new situations; updating of knowledge at the solving of informative and practical tasks.

The activity criterion assumes existence the professional abilities, skills and competences of the solving of professional tasks, existence of abilities to plan and realize their own professional activity. This criterion includes the following indicators: formation of professional abilities; the positive attitude to professional activity at work practice; orientation to creativity in educational professional activity (creativity), aspiration to creative self-expression, originality, development of new technologies and ways of educational professional activity; aspiration to self-improvement (to introspection, a self-assessment, self-education, self-realization); academic success and progress; readiness for research activity; ability to use methods of control over collective.

The emotional and determined criterion assumes enthusiasm for the professional activity, positive emotional spirit in the course of work. This criterion includes the following indicators: responsibility for obvious and hidden consequences of the actions; confidence of achievement success in professional activity; ability of self-control in the course of professional activity; persistence in vocational training, educational activity and independence; readiness for doing work of no prestige; readiness for starting work from scratch and to develop the new direction; readiness for working overtime.

The reflexive criterion assumes ability to introspection, an objective self-assessment, self-criticism, readiness for overcoming of difficulties, identification and elimination of their reasons. This criterion includes the following indicators: efficiency, self-organization; professional mobility, readiness for work changing; ability to reconsider habitual stereotypes, to change them; ecological well-breeding.

Each of the listed criteria is presented both quantitative (an objective assessment), and qualitative (value judgment) by indicators. The quantitative assessment is defined by a number of accurately developed indicators characterizing the level of the students' readiness for professional activity. Quality standard is carried out by means of various questionnaires, business and role-playing games, discussions, the debates, which allow estimating of the personal and business qualities of students. Estimation of cognitive criterion was carried out by a method of computer testing. Motivational, activity, emotional and determined and reflexive criteria was carried out by a method of supervision, complex quiz, questioning, interviewing, discussions, business and role-playing games of experimental and control groups respondents.

\section{Results}

The following content of activity was offered for selection of perspective students by employers: creation of a commission of experts for work with students of Almetyevsk State Oil Institute testing students since the first course; carrying out selection of students in number of $50 \%$ of total number of students, whom the work will be carried out further with after a third year, by the results of progress and testing; distribution of the selected students to production and professional practice, structural divisions of JSC Tatneft, and also to the enterprises of oil service of JSC Tatneft after finishing their fourth year; distribution of students to structural divisions of JSC Tatneft and the enterprises of oil service for externship passing with simultaneous employment and 
compensation for fulfilled time. The heads of structural divisions of these enterprises come as the heads of degree projects. There is also a competitive selection for employment of students for permanent job to structural divisions of JSC Tatneft and other enterprises of oil service according to the developed criteria.

Table. 1. Gradual content of activity of Almetyevsk State Oil Institute and JSC "Tatneft" in selection and preparing of future experts for the oil branch of industry

\begin{tabular}{|c|c|c|}
\hline Stages & The content of Tatneft activity & The content of Almetyevsk State Oil Institute activity \\
\hline 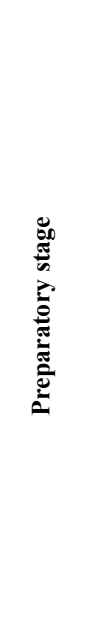 & $\begin{array}{l}\text { - forms the forecast of vacant workplaces; } \\
\text { - creates a commission of experts for work with students of } \\
\text { Almetyevsk state oil institute; } \\
\text { - acquaintance with specifics of educational activity of higher } \\
\text { educational institution (advanced training courses); } \\
\text { - carries out a choice of techniques of diagnostics of students } \\
\text { professional readiness for the future professional activity. } \\
\text { - organizes excursions to the enterprises and professional } \\
\text { consultations for students on the chosen specialty; } \\
\text { - organizes training of teachers at the enterprise and informs about } \\
\text { innovations in production, etc. }\end{array}$ & $\begin{array}{l}\text { - organizes advanced training courses for specialists of the enterprise for } \\
\text { acquaintance with specifics of educational activity; } \\
\text { - develops the training and extracurricular events focused on formation of } \\
\text { competences of graduates; } \\
\text { - develops techniques of diagnostics of students professional readiness for } \\
\text { the future professional activity. } \\
\text { - passes training at the enterprise for the purpose of acquaintance with } \\
\text { innovations at the production; } \\
\text { - involves employers in teaching and educational process of higher } \\
\text { educational institution; } \\
\text { - introduces amendments in working programs for subjects according to } \\
\text { innovations at the production. }\end{array}$ \\
\hline 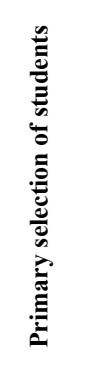 & $\begin{array}{l}\text { - carries out testing of students in each subject and is present at } \\
\text { examinations, since the first course; } \\
\text { - is present at students conferences, seminars to assess students } \\
\text { scientific works; } \\
\text { - invites students, who were distinguished themselves at the } \\
\text { conferences held at the enterprise; } \\
\text { - organizes resource and reserve groups of students. }\end{array}$ & $\begin{array}{l}\text { - creates conditions for employers to carry out computer testing of students } \\
\text { in each subject; } \\
\text { - invites employers to examinations, students conferences, seminars to } \\
\text { assess their works and to identify the most distinguished students; } \\
\text { - organizes training of students on the conference held at the enterprise. }\end{array}$ \\
\hline 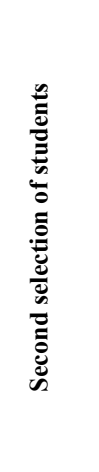 & $\begin{array}{l}\text { - carries out reorganization of resource and reserve groups of } \\
\text { students by results of progress in educational and extracurricular } \\
\text { activities; } \\
\text { - organizes distribution of the selected students to production and } \\
\text { professional and before- diploma practice-; } \\
\text { - forms the list of heads of degree projects from the enterprise; } \\
\text { - creates base with personal data of the selected students. }\end{array}$ & $\begin{array}{l}1 \text { organizes distribution of students to resource and reserve groups; } \\
\text { - reveals potential for work in the system of professional education staff } \\
\text { among students to preserve the continuity of generations at scientific and } \\
\text { technical educational institution; } \\
\text { - reveals the students who are capable to implement the research activity for } \\
\text { study continuation at postgraduate course to provide with staff potential } \\
\text { branch research institutes; } \\
\text { - forms the list of scientific supervisors among teachers of higher education } \\
\text { institution (consultants). }\end{array}$ \\
\hline 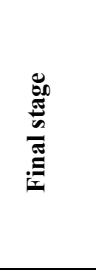 & $\begin{array}{l}\text { - opens an access to information department of the enterprise; } \\
\text { - organizes on-line practical work with the supervisors of degree } \\
\text { projects and top managers of the enterprise; } \\
\text { - participates in the protecting of degree projects; } \\
\text { - introduces amendments in the further solution of joint tasks. }\end{array}$ & $\begin{array}{l}\text { - gives employers opportunity to use an educational and methodical } \\
\text { complex for effective consultation and the management of degree projects; } \\
\text { - organizes protection of degree projects with the invitation of } \\
\text { representatives of production; }\end{array}$ \\
\hline
\end{tabular}

There were the requirements of the enterprises for the staff to professional knowledge and abilities of the graduate of Almetyevsk state oil institute revealed by us. The main of them were: abilities in production and technological activity; abilities in organizational and administrative activity; knowledge in professional activity; meta-professional qualities. Also it should be noted that the students who haven't distinguished themselves by 
results of testing can successfully realize themselves in the research activity which allows defining their professionally significant qualities better on the basis of which their competences are subsequently defined and the complete professional and psychological portrait of the expert is created.

Such approach to process of training of the competitive expert induces the teacher to act as "promoter" of the students and at the same time to maintain the students interest to the subject by attraction of the representative from the enterprise to estimate their work.

The employers realize the necessity of this procedure and mention that in this case the teacher as the research supervisor arms the student who was trained by necessary cogitative means useful for their degree project, the management of which they will have to face. Teachers also note that it helps them to prepare conceptual structure of the subject contents mastered by students according to psycho-physiological opportunities.

Thus, the teacher as the promoter not only makes active, but also optimizes informative activity of students, and the assessment of the employer "has the finger on the pulse" of educational process in order to focus on requirements of production. Especially it should be noted that compliance of functional modules of the professional and directed structured subject contents and the teaching and educational means which are used for purposeful formation of key competences, which provides the advancing nature of vocational training is discussed here.

The necessity of early involving of students in research activity is caused also by that formation of the above-named competences assumes the development of abilities to solve problems among students as well, to find orientation ways in non-standard situations of real professional activity. The former system of selection offered by employers was directed to systematic testing which was limited to the standard solution of the offered tasks with all the advantages and checked only mechanical memory (Masalimova, 2012).

The employers offered to make selection of students in number of $50 \%$ of total number of students for further work after a third year, by results of progress and testing in former registration of the standards. According to our offer procedure of selection there was a decision to organize resource, and also reserve groups of such students. That allowed keeping them "in suspense" of the competition not only in educational, but also in extracurricular activities, independent work and additional self-education. The additional self-education at courses of additional education faculty which allowed them taking part at conferences in a foreign language made them increase the number of hours in the subject "Foreign language" for practical application by the students was also recommended by the employers.

Existence of reserve group didn't allow relaxing those who were involved in the resource group as a total stage was competitive selection. They also formed the portfolio and employers were aware of everything from the very beginning as it contained results noted by them.

The choice of resource and reserve groups with flexible system of transition of students from one group to another is caused by the fact that now there is no system of distribution of graduates of educational institutions which in former times guaranteed them employment according to their profession line. The situation for graduates became aggravated by the circumstance that now distribution is limited. It puts young specialists in system of the rigid competition with experienced experts. Therefore procedure of formation of reserve group served as the certain stimulating factor bringing them to reality that can expect them in the future if they aren't able to find work right after the higher educational institution where the main task of representatives of production and educational institutions of professional education is teaching them various ways of survival. That means the formation throughout study at higher educational institution and passing of production and externships necessary for mobility, for independent creation in their own educational way.

Level of knowledge and practical skills of the students who have passed selection in resource group, according to employers, was low. The selected $50 \%$ of the best students during testing showed the best result- $-75 \%$ of the correct answers. $35 \%$ of all students coped with tasks at good level (from 60 to $75 \%$ ), 17\% performed a half of test tasks (from 45 to $60 \%$ ). These students were organized in resource group who passed work practice according to distribution specially developed on JSC Tatneft.

As it was told above, the place in resource group wasn't assigned "for life" to a student. This selection gave the advantage in practical training, participation in production affairs only before the following round of selection. Thus, the student of resource group should confirm constantly the right for stay in this group and led to essential change in level of assimilation of knowledge and abilities, increase the readiness for knowledge application or for formation of competences.

The selection of students' procedure documenting of estimation of participation of the student by employers was 
introduced into resource group by us at the conferences parallel to introduction of the advanced mechanism of it. The paper of an assessment of the report at a conference was filled in triplicate (to the employer, to the student into portfolio and into archive of letting-out chair) which students showed while employing.

Process of formation of a subject of the degree project, choice of the head and participation in competition to apply for a vacant workplace shows interaction which gives them the following opportunities:

- for students - to elect the head of the degree project independently, to chose the organization for externship passing, to apply for a vacant workplace of the expert, to contact with project managers and top specialists of JSC Tatneft directly;

- for the enterprise - to choose qualitative experts themselves and to train them according to the requirements;

- for the higher educational institution - to raise level of training of specialists, to diversify the directions to those of degree projects and to provide studying of the chosen subject deeper.

The advantages of this mechanism are the following:

- firstly, it prevents realization of measures for transformation of vocational training from discrepancy that subjects really do, and what they can potentially make as activity isn't imposed from the outside and everybody realizes the participation and responsibility for the solving common problems due to the provided measures of feedback;

- secondly, it allows anticipating of changes at the production which can happen soon probably;

- thirdly, it creates conditions for systematic transfer of professional skills and working methods from the senior generations to youth, due to direct contacts with the best experts of production;

- fourthly, it involves students and teachers in basic and applied researches, allowing to keep continuity of scientific and technical schools as it promotes growth of new generation of the researchers focused on requirements of innovative economy;

- fifthly, it provides supporting competitiveness of sector of researches and development in the industry with the developed environment to "generation of knowledge- sixthly, it promotes the students choice of their own educational and career way.

\section{Discussions}

The problem of selection is characterized by a considerable variety of the parameters estimating quality of previous preparation, characterizing experience, opportunities, abilities and knowledge which are saved up and gained by the student for the previous period of training in higher education institution. It should be noted that now there are no researches directed on a solving of the problem of joint tracking and selection of perspective students as by higher educational institutions, and the employers while the selection of students in a magistracy with use of analytical methods for its realization was leading by the following scientists: Zakirova and Stolbov (2014), Kuznetsova and Pakhomov (2009), Petrov, Stolbov, and Gitman (2008), Bedny, Gurbatov, and Mironos (2010), Matushkin and Stolbova (2009), Gitman and Gitman (2010).

Future specialists' professional competence forming aspects are revealed in the researches of Mukhametzyanova (2005), Gaisina (2000), etc.

Modern enterprises shouldn't be interested only in receiving the competent young specialist. At the present time there is the gap between getting professional education at higher educational institution and intensively developing enterprises, therefore, there is a need in joint efforts of institutions of higher education and enterprises in "growing" and selection of perspective students for future professional activity.

\section{Conclusion}

The mechanism of the continuous "involved" selection of students offered by us, by the representatives of the basic enterprises favorably differs from foreign analogs, such as Headhunting, Assessment as it is based not on strategy of "removal of cream", and on cultivation and selection of perspective staff as procedure of selection of perspective students can be reduced not only to identification and selection, and to cultivation and assistance in self-determination of students due to development of steady motivation and installations on continuous self-education, self-determination, self-development, self-presentation at a labor market that considerably promotes increase of competitiveness of university graduates.

Creation of conditions of the natural competitive environment, in this case, makes active adaptive abilities of students due to their inclusion in system of relations of production most approached to real conditions and education - production makes stimulating impact on all the subjects of the integrated system. 


\section{References}

Bedny, B. I., Gurbatov, S. N., \& Mironos, A. A. (2010). Performance Indicators graduate programs in natural sciences. Higher Education in Russia, 7, 11-23.

Gaysina, G. I. (2000). Education as a social and cultural phenomenon (p. 145). Moscow-Ufa.

Gitman, M. B., Gitman, E. K., \& Stolbov, V. Y. (2010). Posgraduate training for innovation. Higher Education in Russia, 5, 102-111.

Ivanov, V. G., Petrov, B. G., Grigoryev, N. S., Sabirzjanov, A. N., \& Kurgannikova, T. I. (2010). Organization attestation of training and certification managers and specialists in industrial safety. Bulletin of Kazan State Technological University, 12, 263-265.

Kuznetsova, T. A., \& Pakhomov, S. I. (2009). Coordination qualification requirements professional and educational standards for graduates. Integration of education, 4, 3-9.

Masalimova, A. R. (2012). Development of research competence of technical specialists in the process of intra-training. Kazan Pedagogical Journal, 93(3), 127-132.

Matushkin, N. N., \& Stolbova, I. D. (2009). Model managment training of scientific personnel in the fielf of engineering and technology for innovation. Innovations in Education, 5, 4-13.

Mukhametzyanova, G. V. (2005). Professional education: Problems of quality and academic support (p. 319). Magarif Press.

Mukhametzyanova, G. V., \& Shaidullina, A. R. (2011). Regional Integration Processes in the Vocational Education System (1st ed., p. 232). Idel Press.

Petrov, V. Y., Stolbov, V. Y., \& Gitman, M. B. (2008). Criteria for assessing the quality of training highly qualified. Higher Education in Russia, 8, 13-19.

Shaidullina, A. R., \& Masalimova, A. R. (2006). Foreign experience of integration of research, teaching and practice of students of higher technical school. Kazan Pedagogical Journal, 5(47), 54-61.

Smirnov, I. P., \& Tkachenko, E. V. (2004). Social partnership: What awaits employers? (Results of the pilot the All-Russian social studies) (p. 32). Aspect Press.

Zakirova, E. I., \& Stolbov, V. Y. (2014). Multiagent decision support system for the selection of students to master college. Control Systems and Information Technology, 11(55), 146-151.

\section{Copyrights}

Copyright for this article is retained by the author(s), with first publication rights granted to the journal. This is an open-access article distributed under the terms and conditions of the Creative Commons Attribution license (http://creativecommons.org/licenses/by/3.0/). 